\title{
Out of School Learning in Study Tour Program For Improving Social Competence Students in Gembira Loka Zoo
}

\author{
Sujarwo $^{\mathrm{a}}$, Tristanti ${ }^{\mathrm{b}}$ \\ Pendidikan Luar Sekolah, University of Yogyakarta \\ Yogyakarta, Indonesia \\ Corresponding e-mail: sujarwo@uny.ac.id ${ }^{\mathrm{a}}$, tristanti@uny.ac.id ${ }^{\mathrm{b}}$
}

\begin{abstract}
The activity of out of school learning purpose to develop social competence and morality of students because this activity have done together and responsibility so that it can to develop student ability. The aims of this research are; (1) understand the implementation of out of school learning in study tour program in Gembira Loka Zoo for improving the social competence students, (2) improving the social competence of students through out of school learning at the zoo. This research is participatory action research that conducted by implement the out of school learning based on zoo potential in Gembira Loka. The result of this research are; 1) the step of out of school learning in study tour program is conducted through; planning is a guide doing planning activities a few days before doing activities out of school learning assistance. In this planning the guide prepared the materials, instruments, and subtances that will be needed in activity of out of school learning that is outing class. The implementation of the out of school learning includes: a) instructure split up tasks in preparing instruments and materials to be used in out of school learning, b) instructors welcoming and establishing intimacy with the participants of outing class, c) building of the athmosphere that undertaken by the instructor to participants where participants are gathered in the wide area to encourage participants to be followed by guidence introduction, d) the activity of the creative corner that is skill activity which still related to education and tourism, e) result of the creativity given to each participants, f) tour the zoo the participants that accompanied by instructor. Evaluation conducted by the guide to the participants at the end of the creative corner. The technique that use in evaluation is recalling techniques. From this recalling can be known level of understanding of participant after doing activity of outing class activity. 2) outing class in study tour program can improve social competence of learners on aspects cooperation skills, communication skills and adaptability skills.
\end{abstract}

Keywords: $\quad$ out of school learning, study tour, social competence

\section{INTRODUCTION}

The learning in school has been synonymous with the learning that was held in the classroom. Learners are always confronted with theories that must be memorized and understood. It will only make learners feel bored and depressed. Emphasis on cognitive ability will make learners to be private and not easily communicate with others. Whereas in a person's life, which makes a person acceptable in society because of someone having good social skills. Student social competence can be realized in the learning activities both in class and outside the classroom. But learning outside the classroom will provide more social competence because learners can interact more with both the environment and also with others outside the classroom. Social competence is the ability, skill of an individual in interacting effectively with the environment and influencing others in order to achieve goals in a particular social context tailored to the culture, the environment, the situation faced and the values held by the individual (Paterson and Leigh in Gullota Et al., 1990).

Social competence is needed by learners because students will experience changes in the environmental situation that continues to run. Social competence is also needed as a preparation for learners to adapt to the new environment. When learners enter a new environment, learners experience a process of adjusting for the right knowledge, attitude and behavior to adapt to different physical and social cultural situations. As Zakaria (2004) when a person is unable to find the right adaptation, it will have an effect on the restriction to enter its developmental trajectory. Social skills according to Syamsuddin and Maryani (2008: 6) in Wati (2011) is a skillful ability that appears in action, is able to search, sort and manage information, able to learn new things that can solve everyday problems, Communication 
skills both spoken and written, understanding, respecting, and able to work with others plural, able to transform academic ability and adapt to the development of society.

The social competence of learners has not seemed to look good. This can be explained from the activities of learners during classroom learning. Learners tend to be passive in receiving materials from educators. They are embarrassed to convey ideas, so they often ask personally either through media or communicate directly. The ability of learners in working together in groups to solve a problem is also not well established. In addition, passive attitude in learners also impact on activities outside the classroom. Learners lack good communication in the academic environment both with fellow learners as well as with educators.

Outing class can be an additional learning that has been done only in the classroom. One of the forms of outing class is the outing class that conducted by students from the Out of School Education of Faculty of Education UNY (PLS FIP UNY) held at Gembiraloka Zoo. This activity is carried out based on cooperation between PLS FIP UNY with Gembiraloka Zoo as an laboratorium of campus outside of PLS FIP UNY. The process outing class is done by students PLS FIP UNY who served as a guide and assistant in skills activities. Implementation of learning at Gembiraloka Zoo is meant that when visitors (children) come to Gembiraloka Zoo not only see the various types of animals and enjoy the scenery, but learners gain knowledge and skills that they do not get during the class. Such learning is called a learning tour. Learning tours can also be interpreted as a travel activity by a group of people to learn something like location, culture and tradition. Moeslichatoen (2007: 21), learning tours is one method that conducts teaching activities with the outside world directly that encourages children to get the impression in accordance with what is observed. Through a learning tour program that is packed with a touch of skills to make learners have increased social competence in aspects of skills, cooperation, communication and adaptability.

\section{METHODS}

The research method used action participation research that conducted by implementing outing class based on zoo potential in Gembiraloka. The study was conducted at Gembiraloka Zoo. The subjects of this study are students of Out of School Education UNY who served as a guide of outdoor learning activities in Gembiraloka. Data collection techniques used are observation, interview, and focus group discussion. Instruments used in data collection in this study include the observation sheet and questionnaire sheet. Observation sheets are used to record information from the field and record important events that occur during the lesson.

\section{RESULT AND DISCUSSION}

A. Outing class in Gembiraloka have done through three stages, that are:

1. Planning

At the planning stage, the guides perform planning activities several days before doing outing class assistance. In this planning activity the guide prepares the materials and tools that will be needed in the mentoring activities.

2. The next stage is the implementation which includes:

a) Instructors share tasks in preparing tools and materials to be used in outing class activities.

b) Welcome

The reception is held before the outing class activities begin. Instructors welcome and establish intimacy with participants of outside learning in the form of introductory guides, prayers, and photos together.

c) Build the atmosphere

This atmosphere building activity serves as a warming atmosphere and familiarity of the participants with the guiding team. This activity is led by a lead guide who leads the course of activities on that day. This form of activities in the form of games with lahu and mini outbound.

d) Creative corner

Creative corner of skill activities that are still related to education and tourism. This creative corner activity is an activity aimed to hone the creativity of PLS Gembiraloka zoo program participants. Content in this activity is tailored to the needs and grade levels of the participants. For example: making elephant crowns, making organic fertilizer, milking cows, feeding fish, and planting seeds using polybags.

e) Given of the masterpiece to the participants 
At this stage the work already done by each participant is given back to the participants. The process of making this craft is accompanied by a guide until the participants can finish their work.

f) Tour the zoo

The last stage is to go around the zoo accompanied by the instructor. This activity allows participants to explore their surroundings and make it a learning resource. In this activity the participants can feel and experience firsthand what they are learning. The concept that is highlighted in this activity is rekreatif but still educative.

3. The final stage of the implementation of outing class is evaluation

This evaluation activity is conducted by the guide to the participants when the creative corner activity ends. The method used in the evalution is the recalling technique. This activity is the last activity before the guiding team handed over the students to the school. This activity aims to review what has been gained, experienced and learned by program participants during the program's implementation on that day. The recalling process is that the participants are asked to come forward and tell what they have done during the activity. Recalling serves to know how many participants understand the material that has been given by the guide during the implementation of PLS Gembiraloka zoo program (Sujarwo et al, 2017). This method was chosen because it was able to present the achievement of the material absorption and the purpose of the out-of-school learning. The activity ended with a farewell and greeting between the guiding team and the school escort teachers.

B. Outing class on learning tour program can improve students' social competence on three aspects:

\section{Cooperation skills}

A good collaboration conducted by the guiding team can lead the participants to conduct learning outside the school well and smoothly. In a team of guide guides from 5 guides who will guide the entourage of participants in learning tours. Each guide has different tasks as a mainspeaker, creative corner guides, and also a guide on the zoo tour. However, among the guides working to help each other and complement, so the work can be completed properly.

2. Communication skills
Guides in outside learning activities must have good communication skills. This is because the guide becomes the introduction of the material so that the material presented by the guide to the participants can be delivered correctly. Communication skills undertaken are courageous to speak loudly and fluently in front of the participants outing class, able to polite communication to the guardian of participants and also to participants and other guides, and have an attitude of empathy towards others.

\section{Ability to adapt}

Learning outside of school conducted by the guide (learners) can improve the ability to adapt to the guide. Adaptive ability can be realized in the attitude of able to manage learning outside school well although the guide does not know the character of the entourage participants. In this case the guide is able to recognize the character of participants such as shy, courageous, and also difficult to control. Thus the guide should tailor the material to the needs of the participant.

\section{Discussion}

1. Implementation of outing class at Gembiraloka Zoo

Outing class conducted by PLS FIP UNY students as a guide or companion project is implemented through the stages of planning, implementation, and evaluation. This is intended to facilitate the learning done and in accordance with the needs of the participants outing class. According Nasri (2008: 10-11) stage of mentoring activities include:

a) Preparation Phase

At this stage the guide is prepared to perform assistance. In this stage also performed the perception of inter-guide.

b) Assessment Stage

In this stage the problem identification is done to find out the needs and resources of the participants.

\section{c) Planning Stage}

At this stage the trainee is trained to solve the problems he faces and is assigned to solve the problems at hand.

\section{d) Formulation of the Plan of Action}

In this stage the participants of the activities are grouped to determine what program they will do to solve the existing problems.

e) Activity Implementation Phase 
At this stage the participants realize the planning that has been made before.

f) Evaluation Phase

Guides assigned to oversee this kegiatan.Hal memudahlan to monitor the participants if any unwanted things happen.

g) Termination Phase

thermination phase is a formal termination phase after the activities have been done.

Outing class through study tours can be done well because the guide can do a good planning a few days earlier related to the preparation of various materials and equipment that will be used for creative corner activities. Guides who already have their respective duties are able to carry out their duties properly so that the attitude of responsibility can be realized in each guide. The plans that have been prepared are then implemented in the form of implementation activities. Implementation activities that are preceded by careful planning are intended to minimize possible constraints and find alternative solutions. According to Sujarwo (2013: 94) in order to achieve the goal to be achieved, the facilitator should have the ability to choose methods, media, learning evaluation tools, and utilize them appropriately.

Evaluation activities play an important role in preparing the next program. Through this evaluation an already implemented program can be improved and refined in the next program. Evaluation activities are used to find out how many programs are implemented beneficial to participants who follow the program and become a benchmark in preparing the next program. According Sudaryono (2012: 41), program evaluation aims to know the achievement of program targets and used to determine how far the target of teaching programs is achieved. The benchmark in this evaluation activity is the objectives that have been formulated in the activity planning stage. Evaluation activities conducted in the out-of-school learning through recalling method. Participants are invited to recall the material and benefits of the activities that have been followed before. Through this activity, participants are expected to understand the benefits and materials in depth and give positive impression to the participants.

2. The social competence of outing class program through learning tours

Social competence in outside school learning includes the skills of cooperation, communication skills and adaptation skills. All three skills have been well developed in the guiding person, so they have good selfmanagement starting from the management of heart and mind that will end in the manifestation of behavior. Weissberg (Goleman, 2000) that socially competent individuals have good liver control, but are skilled at solving problems, have intense involvement with peers, have interpersonal effectiveness and popularity, are skilled at solving interpersonal problems, are skilled in overcoming anxiety And skilled in resolving conflicts.

Social competence can be obtained well by learners if there is direct practice in the students themselves. As learning has been done through the learning tour program has provided more experience for learners to develop their social skills. They can communicate directly with the target and the environment. According to Peterson and Leigh (Gullota et al, 1990) states that social competence is the ability, skill, or skill of an individual in interacting effectively with the environment and influencing others in order to achieve goals in a particular social context tailored to the culture, environment, Encountered as well as the value held by the individual.

Learners are also able to make planning activities that must then be done according to the plan together. Thus they have developed an attitude of co-operation. Cooperation between individuals in a team makes their tasks light and get maximum results. The benefits they can gain from the cooperation are able to save time and energy. Learning outside the school requires a strong physical because the learning is a long series that starts from the creative corner, the zoo tour to recalling. In addition to the ability to cooperate the guides have also been able to develop attitudes of adaptation with visitors as well as the environment.

\section{CONCLUSION}

After the text edit has been completed, the paper is ready for From the result of the research, it can be concluded that: (1) outing class activities in Gembiraloka zoo include planning, implementation, and evaluation, (2) outing classl through learning tour able to increase social competence of learners covering cooperation skills, communicate, and adaptable skills. 


\section{REFERENCES}

[1] Albertina Nasri.(2008). Proses Pendampingan. Jakarta: FSIPUI

[2] Gullota, T.P., Adams, G.R., \& Montemayor, R. (Series volume 3). (1990). Developing Social Competence. California: Sage Publication, Inc.

[3] Moeslichatoen, R. (2007). Metode pengajaran di Taman Kanak-Kanak. Jakarta: Rineka Cipta

[4] Sudaryono. (2012). Dasar-Dasar Evaluasi Pembelajaran. ogyakarta: Graha Ilmu

[5] Sujarwo.(2013). Pembelajaran Orang Dewasa (Metode dan teknik). Yogyakarta: Venus Gold Press.

[6] Sujarwo, S., Samsi, I., \& Wibawa, L. (2007). Desain Model Wisata Belajar di
Kebun Binatang Gembiraloka Yogyakarta sebagai Laboratorium Luar Kampus. Jurnal Pendidikan dan Pemberdayaan Masyarakat 4 (1), 90-100. Doi:http://dx.doi.org/10.21831/jppm.v4i1 .12535

[7] Wati Sudarsih.(2011). Kajian Teori. Diakses dalam: http://repository.upi.edu/9748/2/t pkkh 0908374 chapter1.pdf

[8] Zakaria.(2004). Hubungan Antara Kompetensi Sosial dan Kecerdasan Emosi Dengan Prestasi Akademik Pada Mahasiswa Tahun Pertama. Tesis unpublished. Universitas Gadjah Mada, Yogyakarta. 